\title{
Susceptibility to Butirosin and Neomycin B in Bacillus circulans, the Butirosin-producing Organism
}

\author{
By J. E. DOWDING* \\ Department of Biochemistry, University of Leicester, Leicester LE1 7RH
}

(Received 12 February 1979; revised 11 May 1979)

\begin{abstract}
Butirosin, an aminoglycoside antibiotic, is produced by Bacillus circulans B-3312. Experiments using recombined ribosomal and supernatant fractions from this strain and from $B$. megaterium KM have shown that the ribosomes of both are sensitive to butirosin. The aminoglycoside $3^{\prime}$-phosphotransferase present in $\mathbf{B}$. circulans modifies butirosin and neomycin in vitro but confers resistance only to the former in vivo. The phosphotransferase does not modify a detectable amount of extracellular butirosin while mediating resistance to the antibiotic. In vitro, however, the enzyme appears to protect against inhibition by butirosin by inactivating the bulk of the antibiotic in the system. An extrachromosomal element of unknown function has been detected in $B$. circulans.
\end{abstract}

\section{INTRODUCTION}

The mechanisms by which antibiotic-producing organisms determine resistance to their own antibiotics are of considerable practical and theoretical interest (Demain, 1974). Bacillus circulans B-3312, the bacterium which produces butirosin, an aminoglycoside antibiotic related to neomycin, has been shown to synthesize an aminoglycoside 3 '-phosphotransferase which will modify butirosin and other aminoglycosides in vitro (Dowding \& Davies, 1975). The genetic determinant of this enzyme, which was assumed to be chromosomal, was transferred to Escherichia coli and shown to confer resistance to butirosin and a wider range of related compounds (Courvalin et al., 1977).

A second butirosin-producing bacterium, Bacillus vitellinus Z-1159, has also been shown to synthesize an aminoglycoside $3^{\prime}$-phosphotransferase. On the basis of its substrate specificity, it was suggested that this enzyme, which appears to be very similar to the $B$. circulans enzyme, might be responsible for conferring butirosin resistance on $B$. vitellinus (Nakahama et al., 1977).

This paper describes studies on the mechanism of resistance to butirosin and related compounds in B. circulans.

\section{METHODS}

Bacterial strains. Bacillus circulans B-3312 is one of the two original butirosin-producing isolates (Howells et al., 1972) and was obtained from Dr T. G. Pridham, Northern Regional Research Laboratories, Peoria, Ill. 61604, U.S.A. Bacillus megaterium KM was obtained from Dr E. Cundliffe, Department of Biochemistry, University of Leicester.

Preparation and assay of crude extracts. Bacteria were grown and extracts were prepared as previously described (Dowding, 1977). Aminoglycoside-modifying enzymes and antibiotic concentrations were assayed by the phosphocellulose paper binding technique (Haas \& Dowding, 1975).

Preparation of supernatant and ribosomal fractions. Bacillus circulans and B. megaterium were grown by diluting $10 \mathrm{ml}$ of an overnight culture into $11 \mathrm{ML}$ medium $\left(\mathrm{g} \mathrm{l}^{-1}\right.$ : Difco Bacto-Tryptone, 10; Difco Bactoyeast extract, $5 ; \mathrm{NaCl}, 10$ ). Flasks were incubated at $37^{\circ} \mathrm{C}$ with shaking until an $A_{550}$ of 1.0 to 1.4 was reached.

\footnotetext{
* Present address: 26 Haslingfield Road, Barton, Cambridgeshire CB3 7AG.
} 
The cells were harvested, washed once in buffer I (10 mm-Tris/acetate pH 7.8, 10 mM-magnesium acetate, $25 \mathrm{~mm}$-ammonium acetate, $2 \mathrm{~mm}$-dithiothreitol) and ground with twice their wet weight of alumina. Buffer I $(5 \mathrm{ml})$ was then added and the crude homogenate was centrifuged at low speed to remove alumina and any unbroken cells. The extract was then centrifuged at $30000 \mathrm{~g}$ for $30 \mathrm{~min}$ and the supernatant (S30), held in ice, was dialysed against two changes ( 21 each) of buffer I. The ribosome concentration in the S30 fraction was normally 5 to $10 \mathrm{mg} \mathrm{ml}^{-1}$. The S30 fraction was centrifuged at $150000 \mathrm{~g}$ for $2.5 \mathrm{~h}$ and fractions of the supernatant (S150) were stored at $-20^{\circ} \mathrm{C}$. The crude ribosome pellet was resuspended in $5 \mathrm{ml}$ buffer $\mathrm{I}$ at $4{ }^{\circ} \mathrm{C}$, centrifuged at low speed to remove debris and re-pelleted at $150000 \mathrm{~g}$ for $2 \cdot 5 \mathrm{~h}$. The clear ribosome pellet was resuspended in buffer I (one tenth of the volume of the original S30) and fractions were stored at $-20^{\circ} \mathrm{C}$.

Polyphenylalanine synthesis in vitro. Polyuridylic acid [poly(U)]-directed polyphenylalanine synthesis was assayed as follows. Each reaction mixture contained: $10 \mu \mathrm{l}$ HKM buffer [200 mM- $N$-2-hydroxyethylpiperazine- $N^{\prime}$-2-ethanesulphonic acid $(\mathrm{BDH}) \mathrm{pH} 7 \cdot 5,500 \mathrm{~mm}$-potassium acetate, $85 \mathrm{~mm}$-magnesium acetate]; $10 \mu \mathrm{l}$ of a solution containing $0.4 \mathrm{~mm}$-amino acids (except phenylalanine), $25 \mathrm{~mm}$-ATP (Boehringer), 4 mM-GTP (Boehringer), $50 \mathrm{~mm}$-phosphoenolpyruvate (Boehringer) pH $7 \cdot 2 ; 10 \mu 1 \mathrm{~L}-\left[\mathrm{U}-{ }^{14} \mathrm{C}\right]$ phenylalanine (The Radiochemical Centre, Amersham; $50 \mu \mathrm{Ci} \mathrm{ml}^{-1}$, approx. $500 \mathrm{mCi} \mathrm{mmol}^{-1}$ ); $5 \mu 1$ poly(U) (Boehringer; $10 \mathrm{mg} \mathrm{ml}^{-1}$ in water); $5 \mu \mathrm{l}$ transfer RNA (Sigma; $E$. coli, unfractionated; $20 \mathrm{mg} \mathrm{m}^{-1}$ ); $5 \mu \mathrm{l}$ pyruvate kinase (Boehringer; $1 \mathrm{mg} \mathrm{m}^{-1}$ in glycerol); $5 \mu 1$ water; $45 \mu 1$ supernatant (S150); $5 \mu 1$ ribosome suspension. Antibiotic (or water in control experiments) was added after $5 \mathrm{~min}$ incubation at $30^{\circ} \mathrm{C}$. At various times samples $(10 \mu \mathrm{l})$ were removed to tubes containing $1 \mathrm{ml} 10 \%(\mathrm{w} / \mathrm{v})$ trichloroacetic acid (TCA). Samples were heated at 90 to $100^{\circ} \mathrm{C}$ for $20 \mathrm{~min}$ to hydrolyse transfer RNA and filtered on to Whatman GF/C glass fibre discs. Filters were each washed with approximately $20 \mathrm{ml} 5 \%$ (w/v) TCA, dried and counted using $0 \cdot 4 \%(\mathrm{w} / \mathrm{v})$ 2-(4'-tert-butylphenyl)-5-(4"-biphenylyl)-1,3,4-oxadiazole (butyl-PBD) in toluene as scintillant.

Caesium chloride gradient centrifugation. An overnight culture $(1 \mathrm{ml})$ of $B$. circulans was diluted into $20 \mathrm{ml} \mathrm{ML}$ medium containing $1 \%(\mathrm{w} / \mathrm{v})$ glucose and incubated with shaking at $37^{\circ} \mathrm{C}$ for $2.5 \mathrm{~h} ; 2^{\prime}$-deoxyadenosine (Sigma) was added (final concentration $200 \mu \mathrm{g} \mathrm{ml}^{-1}$ ) followed by [methyl ${ }^{3} \mathrm{H}$ ] thymidine (approx. $15 \mathrm{Ci} \mathrm{mmol}^{-1}$; The Radiochemical Centre) to give $10 \mu \mathrm{Ci} \mathrm{ml}{ }^{-1}$. Growth was continued for $3 \mathrm{~h}$; the cells were then harvested, washed once in ML medium and lysed as described by Guerry et al. (1973). The crude extract was centrifuged at $30000 \mathrm{~g}$ for $30 \mathrm{~min}$, mixed with ethidium bromide (final concentration $250 \mu \mathrm{g} \mathrm{ml}^{-1}$ ) and saturated $\mathrm{CsCl}$ solution was added to yield a density of $1.56 \mathrm{~g} \mathrm{ml}^{-1}$. Gradients were centrifuged at 42000 rev. $\mathrm{min}^{-1}$ for 38 to $40 \mathrm{~h}$ in the Ti-75 rotor of a Beckman Spinco L5-65. Fractions were collected on Whatman $3 \mathrm{MM}$ paper discs which were then washed twice in $5 \%(\mathrm{w} / \mathrm{v}) \mathrm{TCA}$, twice in ethanol/ether $(1: 1, \mathrm{v} / \mathrm{v})$ and once in ether. Discs were air-dried and counted in toluene containing $0.4 \%$ (w/v) butyl-PBD as scintillant.

\section{RESULTS}

\section{Cell-free protein synthesis}

Figure 1 shows the effect of butirosin on recombined systems from B. circulans and B. megaterium. Bacillus megaterium was used as a control in these experiments as it is not known to produce any antibiotic, it was found to contain none of the known aminoglycoside-modifying enzymes and, being a member of the same genus, it might be expected to yield active mixed cell-free systems with $B$. circulans. Ribosomes and supernatants from the two strains could be recombined to give four systems which actively synthesized polyphenylalanine in response to poly(U); controls in the absence of poly(U) or of ribosomes showed negligible synthesis. Ribosomes of $B$. circulans and B. megaterium were sensitive to butirosin when assayed in the $B$. megaterium $\mathrm{S} 150$ fraction but both could be protected by supernatant from the phosphotransferase-containing strain $B$. circulans. In the case of both types of ribosome with the $B$. circulans S150 fraction, there was a lag of approximately 2 to 3 min after antibiotic addition before synthesis was resumed at the previous rate. This is assumed to represent the time taken by the enzyme to lower the butirosin concentration to a sub-inhibitory level. This conclusion is supported by separate assays of the time course of butirosin phosphorylation in vitro; these assays also revealed the presence of an unspecified ATPase activity in extracts of $B$. circulans. 


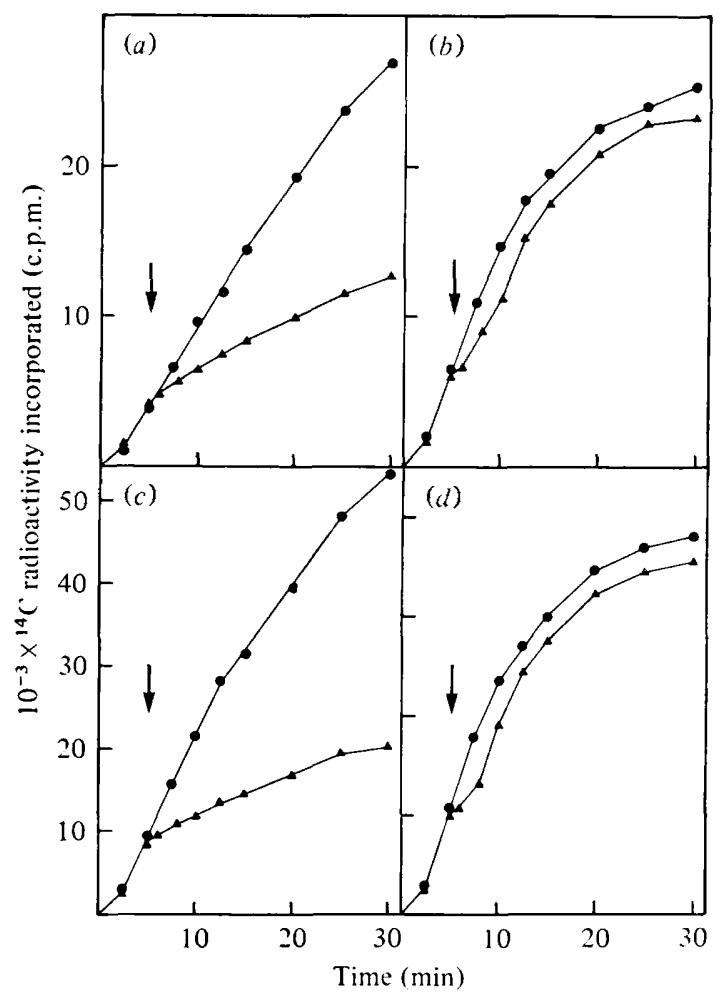

Fig. 1. Poly(U)-directed polyphenylalanine synthesis by recombined ribosomal and supernatant fractions from $B$. circulans and $B$. megaterium (O) and the effect of butirosin $\left(30 \mu \mathrm{g} \mathrm{ml}^{-1}\right)$ on this synthesis $(\boldsymbol{A})$. The arrow indicates the time of addition of butirosin. (a) B. circulans ribosomes plus B. megaterium supernatant; (b) B. circulans ribosomes plus B. circulans supernatant; (c) B. megaterium ribosomes plus $B$. megaterium supernatant; $(d) B$. megaterium ribosomes plus $B$. circulans supernatant.

\section{Resistance to aminoglycosides in vivo}

The effect of two structurally related aminoglycosides (butirosin and neomycin B) on the growth of $B$. circulans was tested. The antibiotics were added to exponentially growing cultures in ML medium (doubling time $48 \mathrm{~min}$ ) at an $A_{550}$ of 0.2 . Although neomycin B is a better substrate for the phosphotransferase than butirosin in vitro (Courvalin et al., 1977; J. E. Dowding, unpublished results), growth of B. circulans was completely inhibited by neomycin B but was unaffected by butirosin. Measurement of the concentration of antibiotic remaining in the supernatant during the course of the two experiments showed that in neither case did the concentration fall measurably from the initial level $\left(30 \mu \mathrm{g} \mathrm{ml}^{-1}\right)$. Thus resistance of $B$. circulans to butirosin is not mediated by inactivation of the bulk of the antibiotic in the medium.

\section{Plasmid DNA in B. circulans}

There has recently been increasing interest in the involvement of plasmids in both antibiotic production (Hopwood, 1978) and antibiotic resistance in antibiotic-producing organisms (Freeman \& Hopwood, 1978). This prompted the examination of B. circulans for the presence of extrachromosomal DNA. The distribution of radioactive material in a typical buoyant density gradient demonstrates that a plasmid is present (Fig. 2). Attempts to transform E. coli C600 with this plasmid by the method of Cosloy \& Oishi (1973) were unsuccessful. Plasmid DNA was isolated from $\mathrm{CsCl}$ gradients or prepared as described by Guerry et al. (1973) and selection was with a range of concentrations $\left(10\right.$ to $\left.50 \mu \mathrm{g} \mathrm{ml}^{-1}\right)$ of 


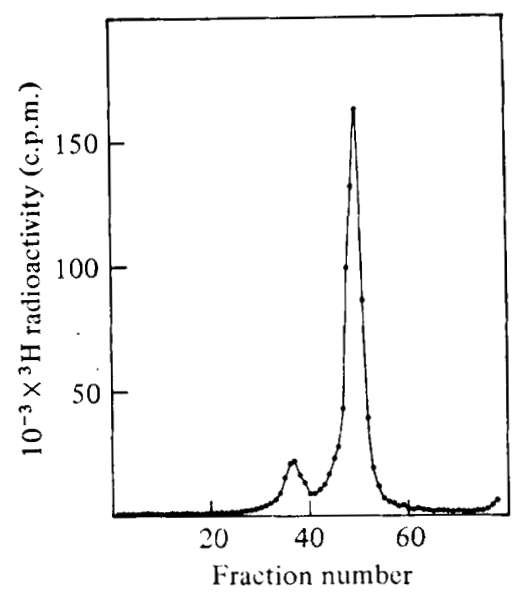

Fig. 2. Caesium chloride-ethidium bromide density gradient of $B$. circulans DNA labelled with $\left[\right.$ methyl $\left.-{ }^{3} \mathrm{H}\right]$ thymidine.

butirosin or neomycin. A number of colonies resistant to both butirosin (up to $30 \mu \mathrm{g} \mathrm{ml}^{-1}$ ) and neomycin (up to $20 \mu \mathrm{g} \mathrm{ml}^{-1}$ ) were obtained with either selective agent, but none of those tested contained detectable butirosin-phosphorylating activity. These isolates were assumed to be low-level permeability mutants and were not examined for the presence of plasmid DNA. Although inconclusive, these experiments suggested that the plasmid does not code for the phosphotransferase; whether it is involved in butirosin synthesis in any way remains to be determined.

\section{DISCUSSION}

It is becoming clear that different antibiotic-producing organisms respond to the compounds they synthesize with fundamentally different mechanisms of self-defence. Streptomyces azureus, for example, which produces the ribosome-inhibitor thiostrepton, has recently been shown to methylate its ribosomal RNA and thereby render the target for the antibiotic refractory to it (Cundliffe, 1978). The cell-free protein synthesis experiments reported here show that the ribosomes of $B$. circulans are sensitive to butirosin, also an inhibitor of ribosomal function, although they can be protected by the supernatant fraction which contains phosphotransferase activity.

This paper confirms the earlier finding (Courvalin et al., 1977) that although the enzyme can modify neomycin in vitro this is apparently insufficient to confer resistance in vivo. This contrasts with the situation in E. coli (Courvalin et al., 1977) where the same enzyme has been reported to determine resistance to neomycin as well as to butirosin and other aminoglycosides. In these experiments, however, selection in $E$. coli was with neomycin and this technique may have selected a cell-enzyme combination with altered permeability to aminoglycosides and hence a different resistance phenotype.

As yet, there is only circumstantial evidence that the modifying enzyme present in B. circulans mediates resistance to butirosin in this organism, as opposed to being involved in an earlier stage of butirosin synthesis for example, although the experiments described here and elsewhere (Courvalin et al., 1977; Nakahama et al., 1977) make this seem very likely. Direct evidence would come from the isolation of a butirosin-sensitive mutant which had lost the ability to produce the phosphotransferase. As such a mutation may be lethal in the event of butirosin synthesis, this type of strain would have to be maintained under 
conditions unfavourable for antibiotic production or, alternatively, isolated in a nonproducing mutant of the parent organism. Any role in antibiotic production (or resistance) of the plasmid detected in B. circulans may, likewise, be elucidated by the isolation of 'cured' derivatives.

This work was supported by a Medical Research Council grant to E. Cundliffe. I wish to thank Dr A. N. Hobden and Mr M. J. R. Stark for many useful discussions.

\section{REFERENCES}

CosLoy, S. D. \& OISHI, M. (1973). The nature of the transformation process in Escherichia coli $\mathrm{K} 12$. Molecular and General Genetics 124, 1-10.

Courvalin, P., Weisblum, B. \& Davies, J. (1977). Aminoglycoside-modifying enzyme of an antibiotic-producing bacterium acts as a determinant of antibiotic resistance in Escherichia coli. Proceedings of the National Academy of Sciences of the United States of America 74, 999-1003.

Cundliffe, E. (1978). Mechanism of resistance to thiostrepton in the producing organism Streptomyces azureus. Nature, London 272, 792-795.

Demain, A. L. (1974). How do antibiotic producing micro-organisms avoid suicide? Annals of the New York Academy of Sciences 235, 601-612.

DowDING, J. E. (1977). Mechanisms of gentamicin resistance in Staphylococcus aureus. Antimicrobial Agents and Chemotherapy 11, 47-50.

Dowding, J. E. \& Davies, J. (1975). Mechanisms and origins of plasmid-determined antibiotic resistance. In Microbiology-1974, pp. 179-186. Edited by D. Schlessinger. Washington: American Society for Microbiology.

Freeman, R. F. \& Hopwood, D. A. (1978). Un- stable naturally occurring resistance to antibiotics in Streptomyces. Journal of General Microbiology 106, 377-381.

Guerry, P., Leblanc, D. J. \& Falkow, S. (1973). General method for the isolation of plasmid deoxyribonucleic acid. Journal of Bacteriology 116, 1064-1066.

HAAS, M. J. \& Dowding, J. E. (1975). Aminoglycoside-modifying enzymes. Methods in Enzymology 43, 611-628.

HopwOod, I). A. (1978). Extrachromosomally determined antibiotic production. Annual Review of Microbiology 32, 373-392.

Howells, J. D., ANDerson, L. E., Coffey, G. L., Senos, G. D., Underhill, M. A., Vogler, D. L. \& ErLICH, J. (1972). Butirosin, a new aminoglycosidic antibiotic complex: bacterial origin and some microbiological studies. Antimicrobial Agents and Chemotherapy 2, 79-83.

Nakahama, K., Shirafuit, H., Nogami, I., Kida, M. \& YoNedA, M. (1977). Butirosin 3'-phosphotransferase from Bacillus vitellinus, a butirosinproducing organism. Agricultural and Biological Chemistry 41, 2437-2445. 